\title{
In Silico Study and Preclinical Evaluation of Radioiodinated Procaterol as a Potential Scintigraphic Agent for Lung Imaging
}

\author{
M. H. Sanad ${ }^{1 \#}$, G.M.Saleh ${ }^{2}$ and H.M.Talaat ${ }^{1}$ \\ ${ }^{1}$ Labeled Compounds Department, Radioisotopes Production and Radioactive Sources \\ Division, Hot Laboratories Center and ${ }^{2}$ Health Radiation Research Department \\ (Radiodiagnosis Unit), National Center for Radiation Research and Technology \\ Atomic Energy Authority, P.O. Box 13759, Cairo-Egypt.
}

\begin{abstract}
$\mathbf{P}$ ROCATEROL has been labeled using $\left[{ }^{125 / 131} \mathrm{I}\right]$ with chloramine-T (Ch-T) as oxidizing agent which can be used for lung imaging instead of the commercially available complex (Macro-aggregated albumin complex, ${ }^{99 \mathrm{~m}} \mathrm{Tc}-\mathrm{MAA}$ ) which is called blood-derived product. In addition, a comparison between a new radiotracer and other radiotracers such as ${ }^{99 \mathrm{~m}} \mathrm{Tc}$ DHPM, ${ }^{99 \mathrm{~m}} \mathrm{Tc}(\mathrm{CO})_{5} \mathrm{I}, \quad{ }^{125 / 123} \mathrm{I}$-IPMPD, ${ }^{125} \mathrm{I}$-fenoterol,${ }^{125} \mathrm{I}$-reproterol, ${ }^{125} \mathrm{I}$-levalbuterol, ${ }^{99 \mathrm{~m}} \mathrm{Tc}$ levosalbutamol and ${ }^{99 \mathrm{~m}} \mathrm{Tc}$-tricarbonyl levosalbutamol is conducted. Factors such as the amount of oxidizing agent $(100 \mu \mathrm{g})$, amount of substrate $(100 \mu \mathrm{g}), \mathrm{pH}$ of reaction mixture (4), ambient temperature and reaction time $(15 \mathrm{~min})$, have been systematically studied to optimize the iodination. Additionally, the in-vitro stability of radioiodinated procaterol was studied in two different media , namely, saline and serum up to 72 hours that indicates its stability upto $12 \mathrm{hr}$. The labeled compound was separated and purified using thin layer chromatography (TLC), paper electrophoreses and high performance liquid chromatography (HPLC). Biodistribution studies indicated the suitability of radioiodinated procaterol as a novel tracer for lungs imaging. Radioiodinated procaterol could be considered a new radiotracer for lung imaging.
\end{abstract}

Keywords: Radioiodinated procaterol, Chloramine-T, $\beta_{2}$-Adrenoceptor, Molecular Modeling and Gamma scintigraphy.

\section{Introduction}

Lung perfusion and ventilation scansknown asa lung perfusion scan is a test performedto indicate how blood flows to the lungs, but the other types ofscan tend toshow how well air and blood flow through all areas of the lungs.In the ventilation phase of the test, a gaseous radionuclide such as xenon or ${ }^{99 m}$ Tc-DTPA in an aerosol form is inhaled by the patient through a mouthpiece or mask that covers the nose and mouth. Ventilation imaging can also be performed using a technegas machine which produces an aerosol of radioactive nanoparticles, specifically carbon nanoparticles containing ${ }^{99 \mathrm{~m}} \mathrm{Tc}$. The perfusion phase of the test involves the intravenous injection of radioactive Macro-aggregated albumin complex, ${ }^{99 \mathrm{~m}} \mathrm{Tc}-\mathrm{MAA}$. A gamma camera acquires images for both phases of the study. A SPECT image can also be taken following an injection of Technetium labelled MAA. SPECT is often skipped if the patient has pulmonary hypertension (JAMA ,1990,
Bajcetal., 2009, Parker etal., 2012, Hofmanetal., 2011, Akkas et al., 2011, Yang et al., 2011,Gu et al.,2011). There were many labeled compounds and complexes made for lungs imaging and perfusion detecting, ventilation, infectionand inflammation process. However, a lot of these complexes have many drawbackssuch as ${ }^{99 \mathrm{~m}} \mathrm{Tc}$ MAA which iscalled Macro-aggregated albumin which complex which is of a wide commercialuse for lung imaging (Sanad, 2014, Klaus et al., 2009, Sanad et al.,2014). In this complex, precapillary arterioles of the lungs is trapped by this radiotracerdue to itsparticles size ( $\sim 30$ microns) (Miroslavov et al.,2009, Seute et al., 2008). In addition, VCJ, HIV, hepatitis $\mathrm{C}$ and hepatitis $\mathrm{B}^{13}$ diseases may cause contamination, whereextracted by human serum albumin. Other radiotracers such as ${ }^{99 \mathrm{~m}} \mathrm{Tc}-\mathrm{DHPM}, \quad{ }^{99 \mathrm{~m}} \mathrm{Tc}(\mathrm{CO})_{5} \mathrm{I}$, ${ }^{125 / 123}$ I-IPMPD， ${ }^{125}$ I-fenoterol， ${ }^{125}$ I-reproterol, ${ }^{125} \mathrm{I}$-levalbuterol, ${ }^{99 \mathrm{~m}} \mathrm{Tc}-$ levosalbutamol and ${ }^{99 \mathrm{~m}} \mathrm{Tc}-$ tricarbonyllevosalbutamolgive maximum lung uptake of $21.4,12.8,10.12 \%, 52.0 \%, 50.6 \%$,

"Corresponding author: msanad74@yahoo.com

DOI :10.21608/ejrsa.2017.1500.1016

(C)2017 National Information and Documentation Center (NIDOC) 
$68.18 \%, 25 \%$ and $56 \% \mathrm{ID} / \mathrm{gm}$ at $15,60,2$, $15,30,30$ and 30 minutes p.i., respectively (Sakr, 2014, Miroslavov et al., 2009, De K et al., 2010, Sanad, and Emad, 2015). Radioiodinated procaterol has been used to avoid the drawbacks of other radiotracers. In this study, ${ }^{131}$ I-procaterol (due to its higher energy compared toiodine-125) was used to determine the accumulation of radioiodinatedprocaterol in lungs of Swiss Albinomice $\quad(25-35 \mathrm{~g})$ usinggamma camera detection.

\section{Materials and Methods}

No-carrier-added (NCA) $\quad \mathrm{Na}^{125} \mathrm{I} \quad(185$ $\mathrm{MBq} / 50 \mu \mathrm{L}$ ) diluted in $0.04 \mathrm{M} \mathrm{NaOH}, \mathrm{pH}$ 9-11 was purchased from the institute of isotopes, Budapest, Hungary. In addition, sodium $\left[{ }^{131} \mathrm{I}\right]$ iodide $(3.8 \mathrm{GBq} / \mathrm{ml})$ diluted in $0.05 \mathrm{M} \mathrm{NaOH}$, $\mathrm{pH} 8$ to 11 for radiolabeling was a gift from RPF, Atomic Energy Authority, Egypt. All chemicals such as procaterol, chloramine-T [N-chloro-ptoluene sulfonamide salt $(\mathrm{Ch}-\mathrm{T})$ ], were purchased from Sigma-Aldrich and were of analytical or clinical grade,used directly without further purification unless otherwise stated. Thin layer chromatography (TLC) aluminum sheets $(20 \times$ $25 \mathrm{~cm}) \mathrm{SG}-60 \mathrm{~F}_{254}$ were supplied by Merck and were detected with a NM UV lamp.Whatman paper number (PC) 1was supplied by Whatman International Ltd, Maidstone, Kent, UK. The development process has been investigated using a mixture of chloroform: ethanol (9:1 $\mathrm{v} / \mathrm{v})$, in which radioiodinated procaterol moved across the mobile phase $\left(R_{f}=0.9\right)$, on the other hand,radioiodide $\left(\mathrm{I}^{-}\right)$remained at $\left(\mathrm{R}_{\mathrm{f}}=0-0.1\right)$ close the origin. Then, strips were removed, dried and cut into one $\mathrm{cm}$ segments and assayed for radioactivity using SR.7 gamma counter. The percentage of radiotracer was confirmed by the ratio of the radiotracer activity to the total activity of all specious multiplied by 100 . High performance liquid chromatography (HPLC) column using a Shimadzu model detector SpD$6 \mathrm{~A}$ the column (RP-C18-250 $\mathrm{mm} \times 4.6 \mathrm{~mm}, 5 \mu \mathrm{m}$, Li Chrosorb) model which consists of pumps LC9A, Rheodyne injector and UV spectrophotometer detector was utilized. The mobile phase, phosphate buffer ( $\mathrm{pH} 3.10)$ and methanol (70:30) v/v), was delivered at $1.0 \mathrm{~mL} / \mathrm{min}$. UV $255 \mathrm{~nm}$. HPLC analysis gave purity for radioiodinatedprocaterol of $99 \%$. The $\mathrm{R}_{\mathrm{t}}$ values of free iodide, procaterol and iodoprocaterolwere 4.0, 9.4 and $11 \mathrm{~min}$, respectively (Fig. 2a \& b), and $\left[{ }^{125} \mathrm{I}\right]$ iodoprocaterol co-eluted with unlabellediodoprocaterol.
Differences in the $R_{t}$ iodoprocaterol and radioiodinatediodoprocaterolmay be due to the increased hydrophobicity upon incorporation of iodine into the aromatic ring.A well-type $\mathrm{NaI}$ scintillation $\gamma$-Counter model Scalar Ratemeter SR7 (Nuclear Enterprises Ltd., USA) was used for radioactive measurement.The radiochemical conversion was further confirmed by paper electrophoresis (PE) using Whatman paper no one ( $2 \mathrm{~cm}$ width and $47 \mathrm{~cm}$ length), $2-5 \mu l$ of the reaction mixture placed at $12 \mathrm{~cm}$ from the negative electrode edge of the paper sheet. Electrophoresis andcarried out for 1.5 hour at a voltage of 300 using normal saline $(0.9 \% \mathrm{w} / \mathrm{v} \mathrm{NaCl}$ solution $)$ or buffer solution $\mathrm{pH} 7$ as electrolytes. On completion of the development, the paper was removed, dried, cut into $1 \mathrm{~cm}$. wide strips, and the strip counted in a $\gamma$-counter.The body distribution profile in mice was recorded using a gamma camera with a 5-mm pinhole collimator, window setting of $190 \mathrm{KeV}$, and $20 \%$ width for gammaimaging studies. After intravenous administration of radioiodinated procaterol (injected dose: $0.1 \mathrm{mg}$ procaterol in $0.5 \mathrm{~mL}$ phosphate buffer $(\mathrm{pH} 4)$, activity: $0.2 \mathrm{mCi}$ ), was animals were anesthetized by intramuscular injection of xylazine $(10.0 \mathrm{mg} /$ $\mathrm{kg})$ and $0.5 \mathrm{~mL}$ of ketamine hydrochloride $(100.0$ $\mathrm{mg} / \mathrm{kg}$ ) for $5 \mathrm{~min}$ before imaging. The doses were given according to Laboratory Animal Sciences Program in NCI Fredric Center for Cancer Research, and this anesthetic agent is believed to have a negligible effect on both blood pressure and the biodistribution of the radiolabeled samples. The animals were fixed promptly on a board in the posterior anterior position and imaging was performed at different time intervals using a gamma camera. The images were taken in the two positions anterior and posterior. Thegammacamera images were acquired at 5,15,30,60, and 120min after injectionusingSwiss Albino mice weighing 25-35 gm $(\mathrm{n}=5,25$ mice $)$. The static images were stored in a 512x 512 matrix size and acquisition times were 300s. Scintigraphy was the diagnostic nuclear medicine test used in this study, where radioiodinatedprocaterolwas administered intravenously and the emitted gamma radiation captured by the gamma camera (Philips axis gamma 2)to form two-dimensional images. Finally, the uptake of each organ can be calculated as the percentage of the injected dose per gram $(\%$ $\mathrm{ID} /$ gram $\pm \mathrm{SD}$ ). The data were estimated with one way ANOVA test. Results for $P$ were reported and all the outcomes were given as mean \pm SD.The in-vitro stability of radioiodinatedprocaterolwas 
studied in two different media. It was found to be stable in saline for up to 72 hours. In contrast, in serum after 24 hours, the purity dropped to $97.0 \%$ then decreased to $85 \%$ at $72 \mathrm{~h}$. using TLC technique for the determination of the radiochemical purity of complex and counted in a well-type $\gamma$-scintillation counter (Sanad etal., 2015, Sanad etal., 2017,Sanad etal.,2016; Sanad etal.,. 2017, Sanad, 2014). The reaction mixture volume was fixed to $\sim 680 \mu \mathrm{L}$. $\left[{ }^{131} \mathrm{I}\right.$ or $\left.{ }^{125} \mathrm{I}\right] \mathrm{NaI}$ (7.5MBq in $0.1 \% \mathrm{NaOH}$ ) was added totwo necked round bottomed flask $(25 \mathrm{ml})$ fitted with a reflux condenser and a rubber septum immersed in a thermostatically controlled water bath and evaporated to dryness. Accurately weighed $100 \mu \mathrm{g}$ $\mathrm{Ch}-\mathrm{T}$ was added to the reaction flask, followed by procaterol $(100 \mu \mathrm{g})$ dissolved in water $(1 \mathrm{mg}: 1 \mathrm{~mL})$. The reaction mixture was stirred with a magnetic stirrer at ambient temperature for $15 \mathrm{~min}$. Then $300 \mu \mathrm{g}$ of $\left(60 \mathrm{mg} / \mathrm{ml} \mathrm{H}_{2} \mathrm{O}\right)$ sodium metabisulphite was added to decompose the excess of iodine in order to stop the reaction. The $\left[{ }^{125} \mathrm{I}\right]$ iodoprocaterol was purified by HPLC (Fig.2a\&b). Fractions of a volume $1.0 \mathrm{~mL}$ were collected separately up to a volume of $15 \mathrm{~mL}$ and counted with a $\gamma$-ray scintillation counter. Inhibition study has confirmed that the radiotracer is accumulated specifically with high affinity binding located in lungs cell by $\beta_{2}$ receptors. Then cold procaterol $(50 \mu \mathrm{g} / \mathrm{kg}$ of mouse) was injected with variable concentration at 15 minute before injecting of radioiodinatedprocaterol(Sanad, 2014).Docking simulations were performed using the $\mathrm{x}$-ray crystallographic Structure of B2-adrenergic (PDB code: $2 \mathrm{RH} 1)$ bound to (S)-Carazolol ((2S)-1-(9HCarbazol-4-yloxy)-3-(isopropyl amino) propan2-ol) CAU. The PDB file was retrieved from Protein Data Bank of the Research Collaboration for Structural Bioinformatics from (RCSB) website [www. rcsb. org]. Structure of chain A was processed using the Structure Preparation application in Molecular Operating Environment (MOE), 2008.10. Subsequently, the protonate 3D application of MOE was used to add the missing hydrogen and properly assign the ionization states. The resultant model was further refined by energy minimization to a gradient of $0.01 \mathrm{kcal}$ mol A_2 keeping atoms tethered within $0.5 \AA$ from their crystal structure positions. The default procedure in the MOE Dock application was used to find the favorable binding configurations of the studied ligands. Initial placement poses generated by the Alpha Triangle matcher were rescored and filtered using the London dG Scoring method to pick those exhibiting maximal hydrophobic, ionic, and hydrogen-bond contacts to the protein. This was followed by a refinement stage. The generated poses were energy minimized using the MMFF94x force field. Finally, the optimized poses were ranked using the GBVI/ WSA DG free-energy estimates as shown in Fig. 7. Docking poses were visually inspected and interactions with binding pocket residues were analyzed(Molecular Operating Environment (MOE), 2008, Paul, 2009,Naïm, etal., 2007, Elgemeieetal.,2017,Dakshayani etal., 2016).

\section{Results and Discussion}

\section{Optimization Reaction}

The $\mathrm{pH}$ of the reaction mixture, amount of the oxidizing agent (chloramine-T (Ch$\mathrm{T})$ ), amount of the ligand, and reaction time of the mixture were optimized at ambient temperature. Fig. 3a showsthat the conversion to radioiodinatedprocaterol increased up to a ceiling of $100 \mu \mathrm{g}$ of Ch-T giving an optimum radiochemical conversion of $98.5 \pm 0.12 \%$, other reaction parameters were kept constant. Excess Ch-T may lead to the formation of undesirable oxidative by-products such as chlorination and polymerization. Hence 100ug of $\mathrm{Ch}-\mathrm{T}$ gave optimum conversion to $\left[{ }^{\mathrm{\mu g} I}\right]$ iodoprocaterol. In addition, $\mathrm{pH}$ is an important factor in radioiodination (Fig. 3b) which needs to be controlled, $\mathrm{pH} 4$ proved to be optimal which may reflect in part the stability of [ $\left.{ }^{125} \mathrm{I}\right]$ iodoprocaterol. The effect of changing substrate to iodide ratio is shown in fig. $3 \mathrm{c}$. which reveals that the optimum radiochemical conversion to radioiodinatedprocaterol $(98.5 \%)$ at $100 \mu \mathrm{g}$ of procaterol and $\left[{ }^{125} \mathrm{I}\right] \mathrm{Na}(7.5 \mathrm{MBq})$ (Sanad et al., 2015, Sanad et al., 2017,Sanad et al.,2016; Sanad et al.,. 2017, Sanad, 2014). The effect of reaction time was also studied giving a maximum conversion at $15 \mathrm{~min}$. (Fig. 3d).

\section{Molecular Modeling Studies}

The proposed docking algorithm was validated by self-docking in the $\beta 2$-adrenergic (PDB code: 2RH1), by removing the bound ligands from the complex then docking it back into the binding site and the main interactions showed that it has four hydrogen bonds with the key amino acids ASN 312 and ASP 316as shown in Table 2. Furthermore, the top ranked pose exhibited heavy-atom rootmean-square deviation (RMSD) value of 0.5487 $\AA$ from the experimental crystal structure. This result indicates that Molecular Operating Environment (MOE) docking can reliably predict 
docking poses for the studied compounds to $\beta 2$ adrenergic. The binding affinity of the ligand and the tested compounds were evaluated with $\mathrm{S}$ - score. The minimum the docking scoreis the higher the binding affinity to the enzyme complex. Interactive docking using MOE protocol was carried out between the predicted structures and the prepared Ascorbateperoxide se receptor. Each proposed structure gave 10 possible docked poses. The ideal pose of each molecule was selected according to the similarity of its binding mode in the binding site to that of the ligand CAU. The results of the docking study including S-score, interacted amino acids and the length of H-bonds formed of all the compounds and the reference ligand are listed in Fig. 7. In general, the topranked poses obtained from MOE docking show that both procaterol and ${ }^{125} \mathrm{I}$-procaterol proposed structure can interact with 2 RH1 as shown in Table 2 and Fig. 8-10. The docking and binding affinities were as follows:

1- Procaterol has S-score of $-17.0355 \mathrm{kcal} / \mathrm{mol}$ and exhibited three hydrogen bonds with ASN 312 of distances $\left(2.36 \mathrm{~A}^{\circ}\right)$ and ASP 113 of distances $\left(3.06 \mathrm{~A}^{\circ}\right)$ also TYR316 of distances $\left(2.62 \mathrm{~A}^{\circ}\right)$.

2- Radioiodinatedprocaterolproposed structure has S-score of $-15.8179 \mathrm{kcal} / \mathrm{mol}$ and exhibited three hydrogen bonds with ASN 312 of distances $\left(2.46 \mathrm{~A}^{\circ}\right)$ and ASP 113 of distances $\left(1.58,1.82 \mathrm{~A}^{\circ}\right)$.

Conclusively, procaterol and radioiodinated procater olproposed structures can interact with the $\beta_{2}$-adrenergic (PDB code: $2 \mathrm{RH} 1$ ).

\section{Gamma Scintigraphy Imaging Results}

Figure 5 shows that $\left.{ }^{[31} \mathrm{I}\right]$ iodoprocaterolconcentrated in its target organ (lungs) with a maximum at 30 minp.i.

\section{Biodistribution}

Table.1 shows the biodistribution of ${ }^{125}$ I-procaterolin different body organs and fluids. All radioactivity levels are expressed as average percentage-injected dose per gram tissue (\%ID/ gram \pm S.D). Low thyroid uptake at all times indicates that the radioiodinated compound is stable in vivo.Iodoprocaterolis distributed rapidly in blood, liver, intestine, kidneys and heart at $5 \mathrm{~min}$. post injection (p. i.). The uptake within the Egypt.J.Rad. Sci. Applic. 39, No.2 (2017) kidneys increased up to $35.0 \pm 0.19 \%$ at $1 \mathrm{hp} . \mathrm{i}$. and decreased to $7.60 \%$ at $2 \mathrm{~h}$. p.i. This indicated that the tracer is excreted through urinary pathways. After1h, the iodoprocateroluptake notably decreased in the most organs. The maximum accumulation of radioiodinatedprocaterolin lungs significantly increased with time, giving $60 \%$ $\mathrm{ID} / \mathrm{g}$ at $30 \mathrm{~min}$ p.i. that was confirmed by gamma camera analysis (Fig.5). Therefore, ${ }^{125}$ I-procaterol isconsidered more specific as radiotracer for lung imaging than all the radiotracers mentioned above. The published \% ID/gram \pm S.D for a number of common of lung imaging e.g. ${ }^{99 \mathrm{~m}} \mathrm{Tc}-\mathrm{DHPM}$, ${ }^{99 \mathrm{~m}} \mathrm{Tc}(\mathrm{CO}){ }_{5} \mathrm{I}, \quad{ }^{125 / 123} \mathrm{I}$-IPMPD， ${ }^{125} \mathrm{I}$-fenoterol, ${ }^{125} \mathrm{I}$ reproterol, ${ }^{125} \mathrm{I}$-levalbuterol, ${ }^{99 \mathrm{~m}} \mathrm{Tc}-$ levosalbutamol and $\quad{ }^{99 m}$ Tc-tricarbonyl levosalbutamolgave maximum lung uptake of $21.4,12.8,10.12 \%$, $52.0 \%, 50.6 \%, 68.18 \%, 25 \%$ and $56 \%$ ID/ gm at $15,60,2,15,30,30$ and 30 minutes p.i., respectively. The results of the present study indicate that radioiodinatedprocaterolhas a higher $\% \mathrm{ID} /$ gram \pm S.D value than these materials.

\section{Drug inhibition Study}

This study investigated the different amounts of cold procaterol used, $30 \mathrm{~min}$ before the injection of iodoprocaterol, which decreased the lungs uptake ratio from 60 to $7.50 \% \mathrm{ID} / \mathrm{g}$ organ at $30 \mathrm{~min}$ p.i. This results confirm that this radiotracer, $\left[{ }^{125} \mathrm{I}\right]$ iodoprocaterol, has been attached and bind to $\beta_{2}$ receptor located in lungs (Fig. 4).

\section{Conclusion}

An optimized protocol for the synthesis of [ $\left.{ }^{125} \mathrm{I}\right]$ iodoprocaterol in a high yield has been developed by electrophilic substitution mediated by chloramine-T. From biodistribution studies, it was concluded that the radioiodinatedprocaterolhas a high lungs uptake of $60 \% \mathrm{ID} / \mathrm{g}$ at $30 \mathrm{~min}$, confirmed by gamma camera, and remains for up to $2 \mathrm{~h}$. An improvement over recently discovered agents such as ${ }^{99 \mathrm{~m}} \mathrm{Tc}-\mathrm{MAA},{ }^{99 \mathrm{~m}} \mathrm{Tc}-\mathrm{DHPM},{ }^{99 \mathrm{~m}} \mathrm{Tc}(\mathrm{CO})_{5} \mathrm{I}$, 125/123I-IPMPD， ${ }^{125}$ I-fenoterol , , ${ }^{125}$ I-reproterol, ${ }^{125} \mathrm{I}$-levalbuterol, ${ }^{99 \mathrm{~m}} \mathrm{Tc}-$ levosalbutamol and ${ }^{99 \mathrm{~m}} \mathrm{Tc}-$ tricarbonyl levosalbutamol has been observed. 
TABLE 1. Biodistribution of ${ }^{125}$ I-procaterolin normal mice at different times.

\begin{tabular}{lccccc}
\hline \multirow{2}{*}{$\begin{array}{l}\text { Organs and body } \\
\text { fluids }\end{array}$} & \multicolumn{5}{c}{ \% I.D./ gram at different times post injection, min } \\
\cline { 2 - 6 } & $\mathbf{5}$ & $\mathbf{1 5}$ & $\mathbf{3 0}$ & $\mathbf{6 0}$ & $\mathbf{1 2 0}$ \\
\hline Blood & $8.11 \pm 0.15$ & $5.9 \pm 0.77$ & $3.4 \pm 0.19$ & $1.9 \pm 0.01$ & $1.1 \pm 0.01$ \\
Bone & $1.1 \pm 0.01$ & $1.20 \pm 0.002$ & $1.33 \pm 0.001$ & $1.44 \pm 0.001$ & $1.14 \pm 0.003$ \\
Muscle & $1.2 \pm 0.002$ & $1.4 \pm 0.001$ & $1.48 \pm 0.002$ & $1.3 \pm 0.002$ & $1.01 \pm 0.002$ \\
Brain & $0.55 \pm 0.002$ & $0.49 \pm 0.001$ & $0.45 \pm 0.001$ & $0.41 \pm 0.002$ & $0.33 \pm 0.001$ \\
Lungs & $50.0 \pm 0.17$ & $55.3 \pm 0.18$ & $60.0 \pm 0.15$ & $45.66 \pm 0.15$ & $19.0 \pm 0.19$ \\
Heart & $6.1 \pm 0.22$ & $5.11 \pm 0.11$ & $3.5 \pm 0.25$ & $3.1 \pm 0.55$ & $2.11 \pm 0.28$ \\
Liver & $2.6 \pm 0.22$ & $5.95 \pm 0.32$ & $7.6 \pm 0.42$ & $3.40 \pm 0.51$ & $2.85 \pm 0.49$ \\
Kidneys & $14.45 \pm 0.19$ & $16.25 \pm 0.29$ & $29.0 \pm 0.11$ & $35.0 \pm 0.33$ & $6.70 \pm 0.55$ \\
Spleen & $1.8 \pm 0.001$ & $1.35 \pm 0.02$ & $1.20 \pm 0.002$ & $1.1 \pm 0.001$ & $1.0 \pm 0.002$ \\
Intestine & $2.7 \pm 0.02$ & $3.11 \pm 0.30$ & $6.25 \pm 0.18$ & $7.44 \pm 0.15$ & $9.22 \pm 0.19$ \\
Stomach & $1.20 \pm 0.001$ & $1.10 \pm 0.002$ & $1.22 \pm 0.003$ & $1.28 \pm 0.002$ & $0.9 \pm 0.001$ \\
Thyroid & $1.10 \pm 0.002$ & $1.11 \pm 0.002$ & $0.95 \pm 0.002$ & $1.30 \pm 0.001$ & $0.91 \pm 0.001$ \\
\hline
\end{tabular}

Mean \pm SD (mean of five experiments).

TABLE 2. Docking results (binding affinity, ligand amino acids interacted with binding site).

\begin{tabular}{|c|c|c|c|}
\hline Compound & S- score & $\begin{array}{c}\text { Amino acids involved in } \\
\mathrm{H} \text {-bonds }\end{array}$ & $\begin{array}{c}\text { Amino acids involved in } \\
\pi \text {-interaction }\end{array}$ \\
\hline LIGAND ( CAU) & $17.7732-$ & $\begin{array}{l}\text { ASN } 312\left(2.77,1.88 \mathrm{~A}^{\circ}\right) \\
\operatorname{ASP} 113\left(1.67,1.94 \mathrm{~A}^{\circ}\right)\end{array}$ & NO \\
\hline procaterol & $17.0355-$ & $\begin{array}{l}\operatorname{ASN} 312\left(2.36 \mathrm{~A}^{\circ}\right) \\
\operatorname{ASP} 113\left(3.06 \mathrm{~A}^{\mathrm{o}}\right) \\
\text { TYR } 316\left(2.62 \mathrm{~A}^{\mathrm{o}}\right)\end{array}$ & NO \\
\hline${ }^{125}$ I-procaterol & $15.8179-$ & $\begin{array}{c}\operatorname{ASN} 312\left(2.46 \mathrm{~A}^{\circ}\right) \\
\operatorname{ASP} 113\left(1.58,1.82 \mathrm{~A}^{\mathrm{o}}\right)\end{array}$ & NO \\
\hline
\end{tabular}

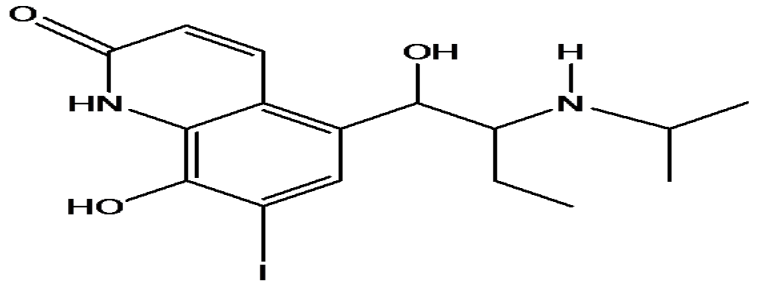

Fig. 1Radioiodination of procaterol. 


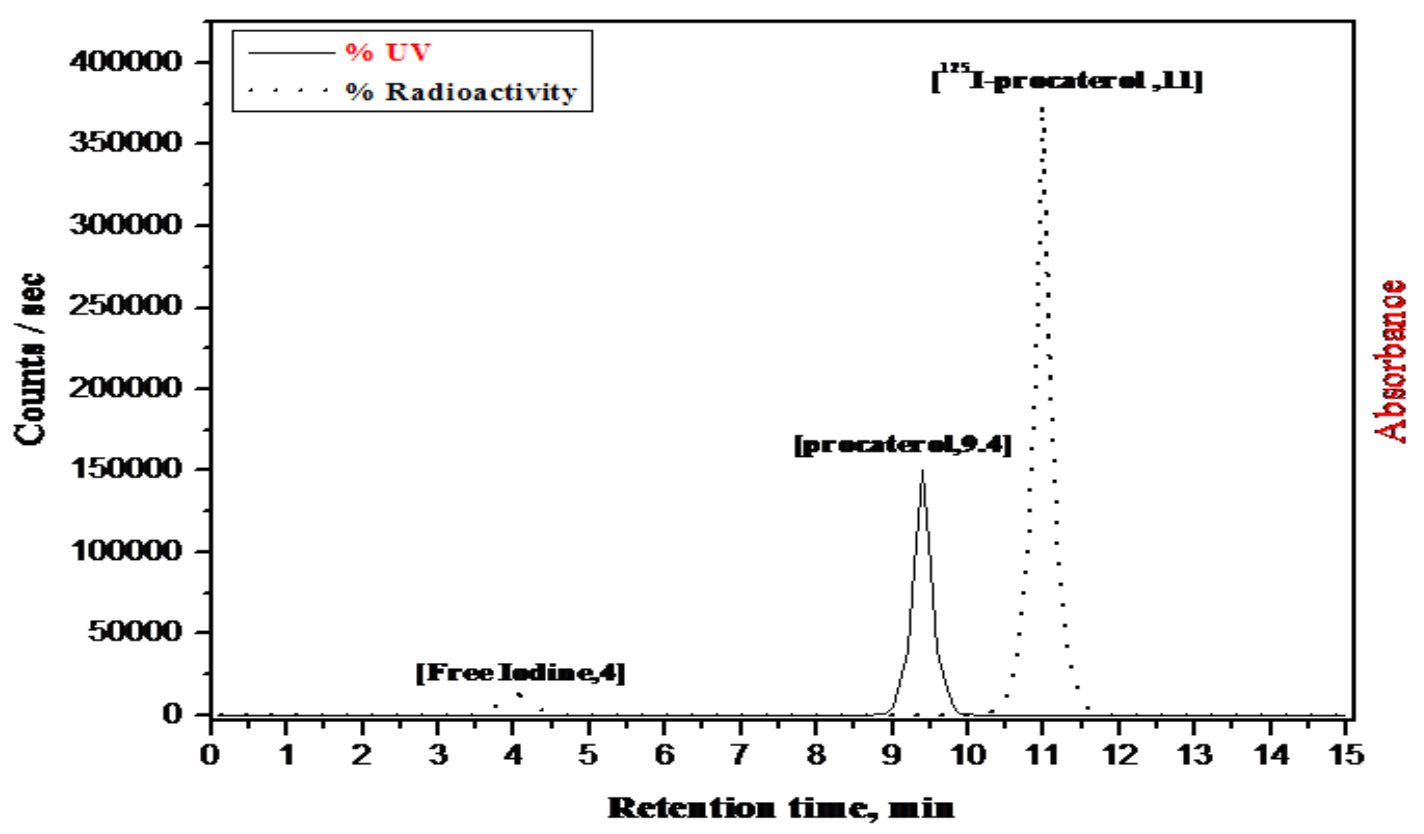

Fig. 2a HPLC radiochromatogram of ${ }^{125}$ I-procaterol.

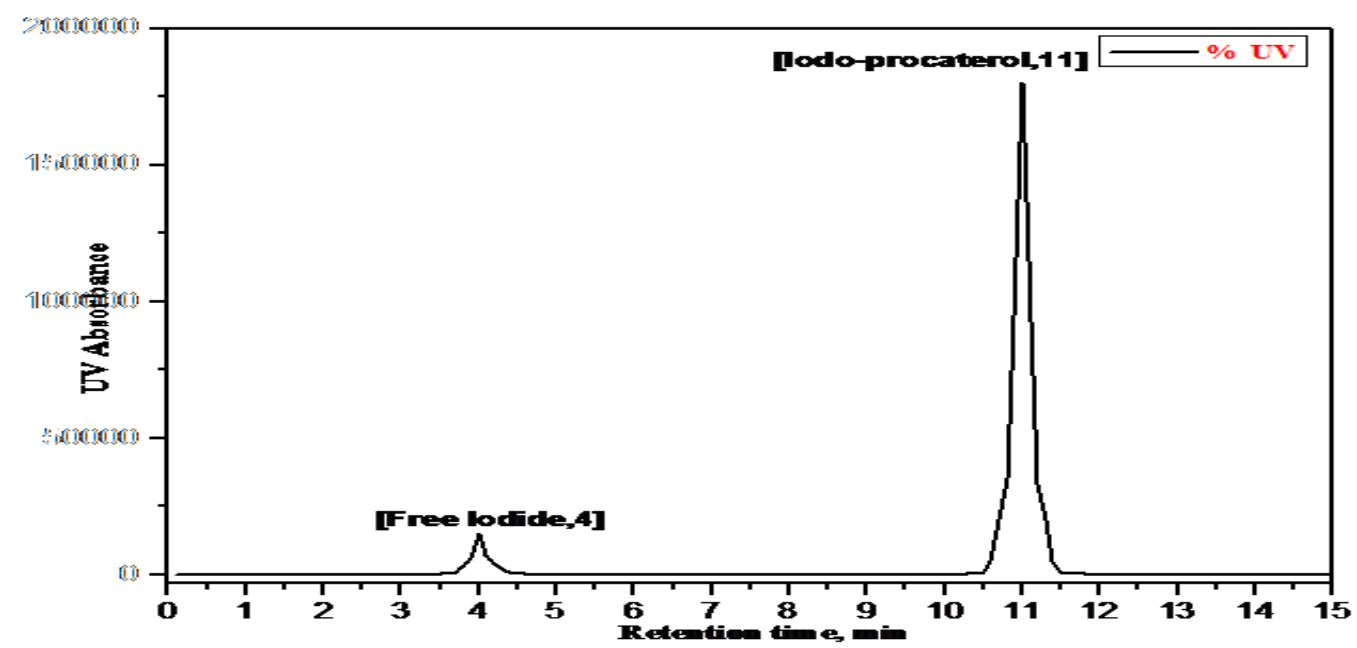

Fig. 2b . HPLC U.V. absorption chromatogram of the reaction mixture of procaterol and KI using Ch-T as oxidizing agent. 

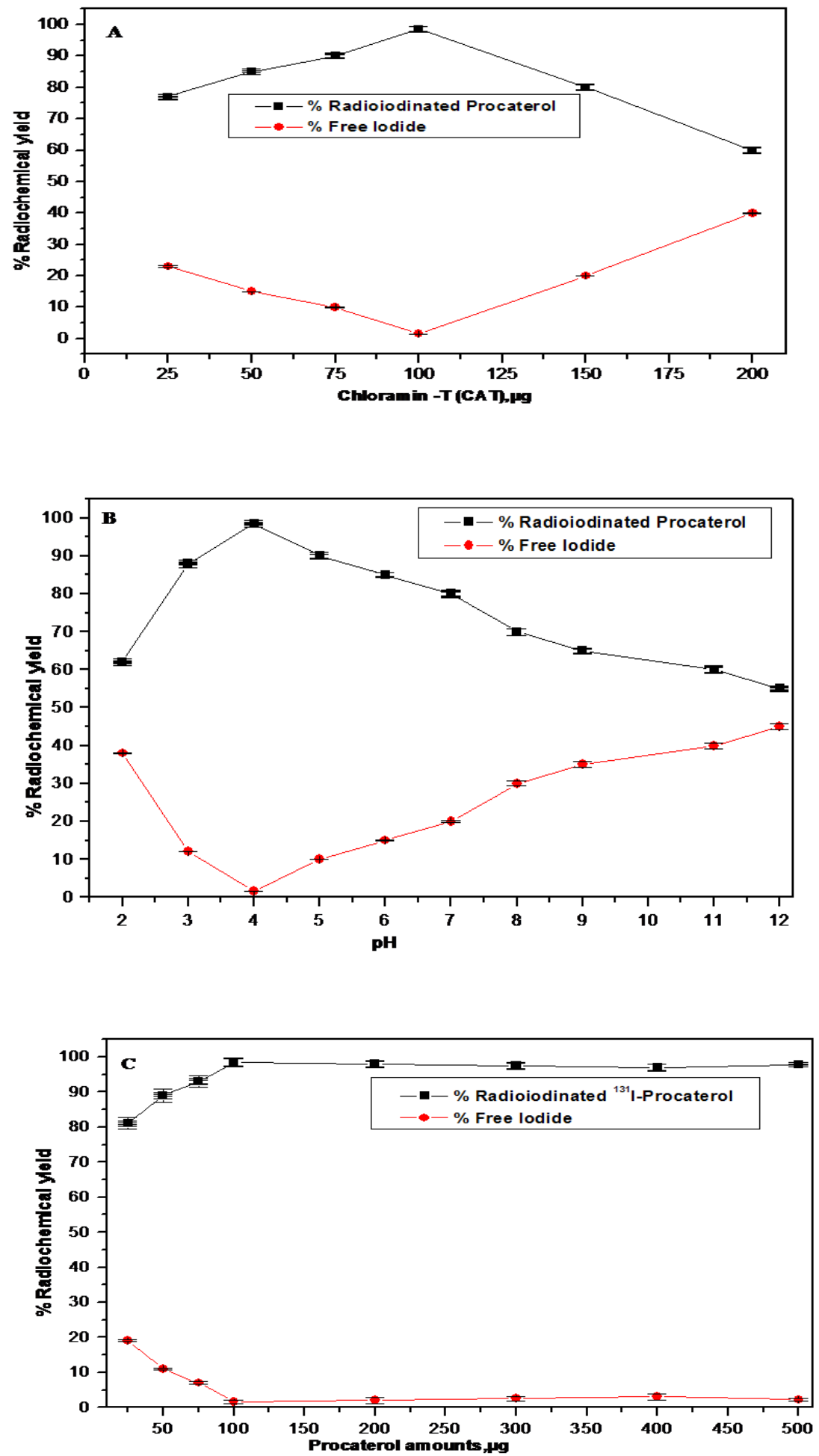

Fig. 3. Variation of the radiochemical yield of radioiodinatedprocaterol as a function of Ch-T amount (A), pH (B), procaterol amount (C) and reaction time (D) 


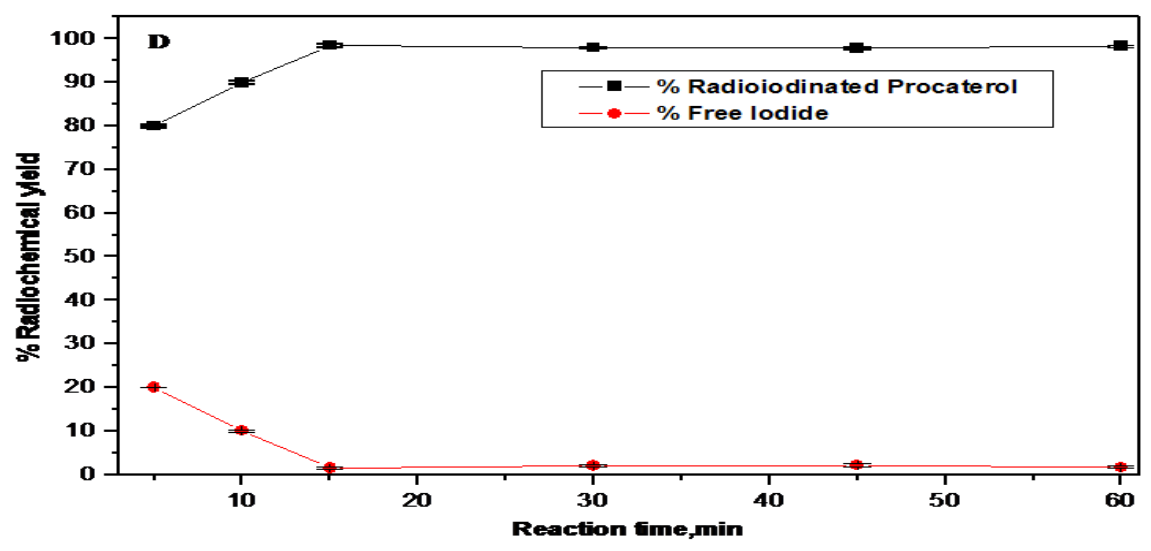

contin.. Fig.3

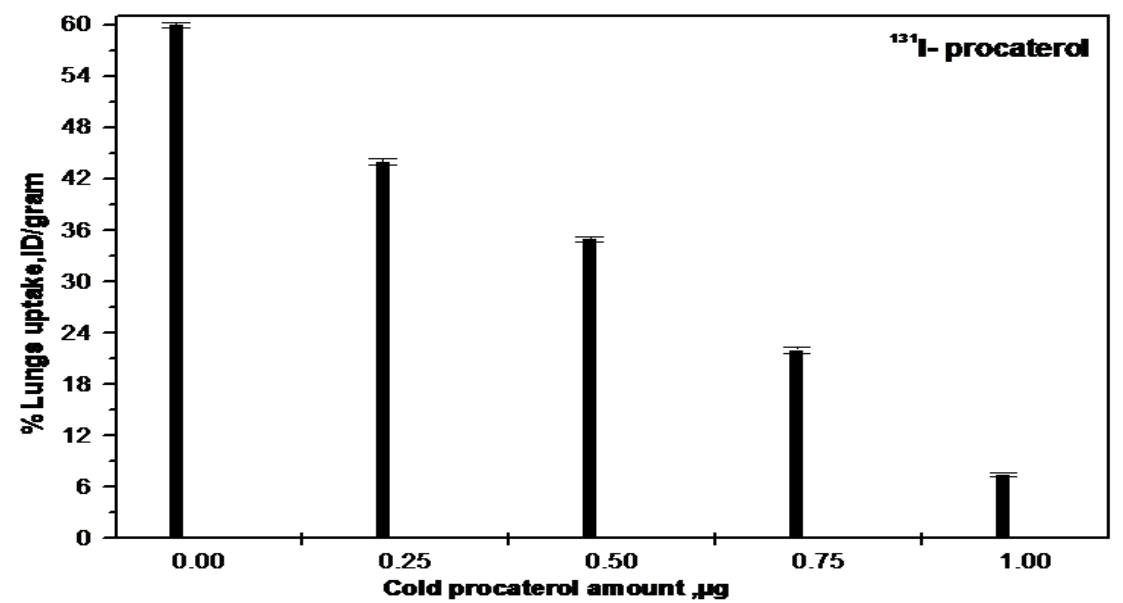

Fig. 4 . ${ }^{125} \mathrm{I}$ - procaterol inhibition lungs uptake in normal male Swiss Albino mice at $30 \mathrm{~min}$ post injection (\%ID/g organ \pm SEM, $n=5$ ).

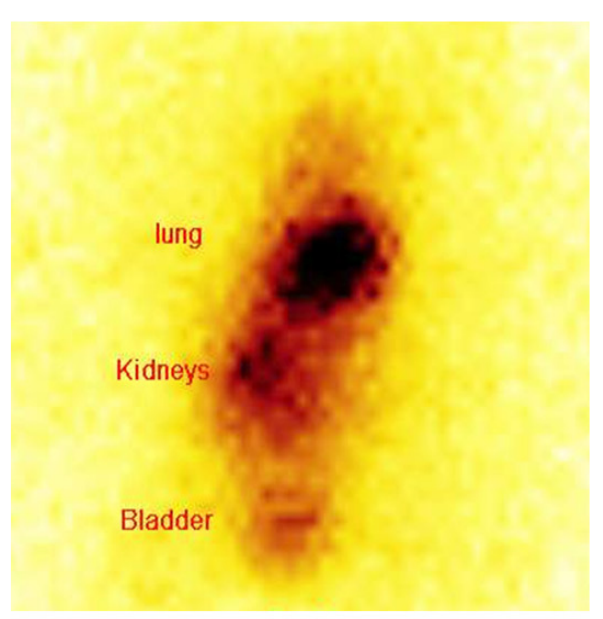

Fig. 5. Gamma Camera Scintigraphy at $30 \mathrm{~min}$ post injection. 

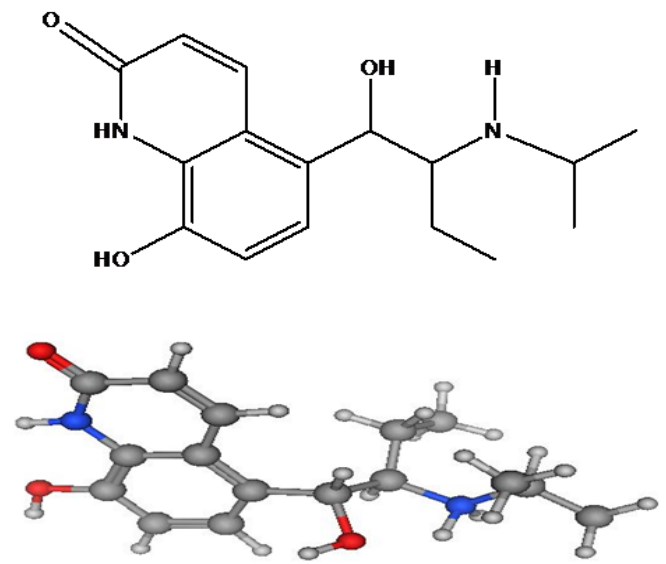

Fig. 6a. Procaterol 2D format and Fig. 6b. 3D after energy minimization.<smiles>CCC(C(O)c1cc(I)c(O)c2[nH]c(=O)ccc12)N(C)C(C)C</smiles>

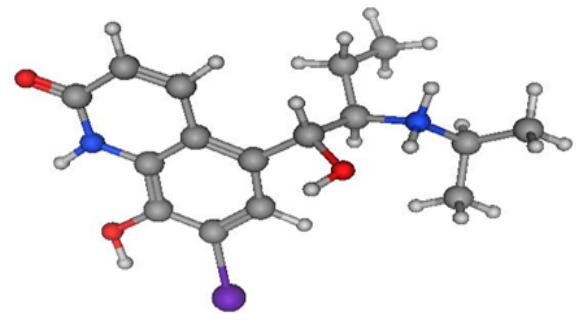

Fig. 7a. Radioiodinated procaterol 2D format and Fig. 7b. 3D after energy minimization. 


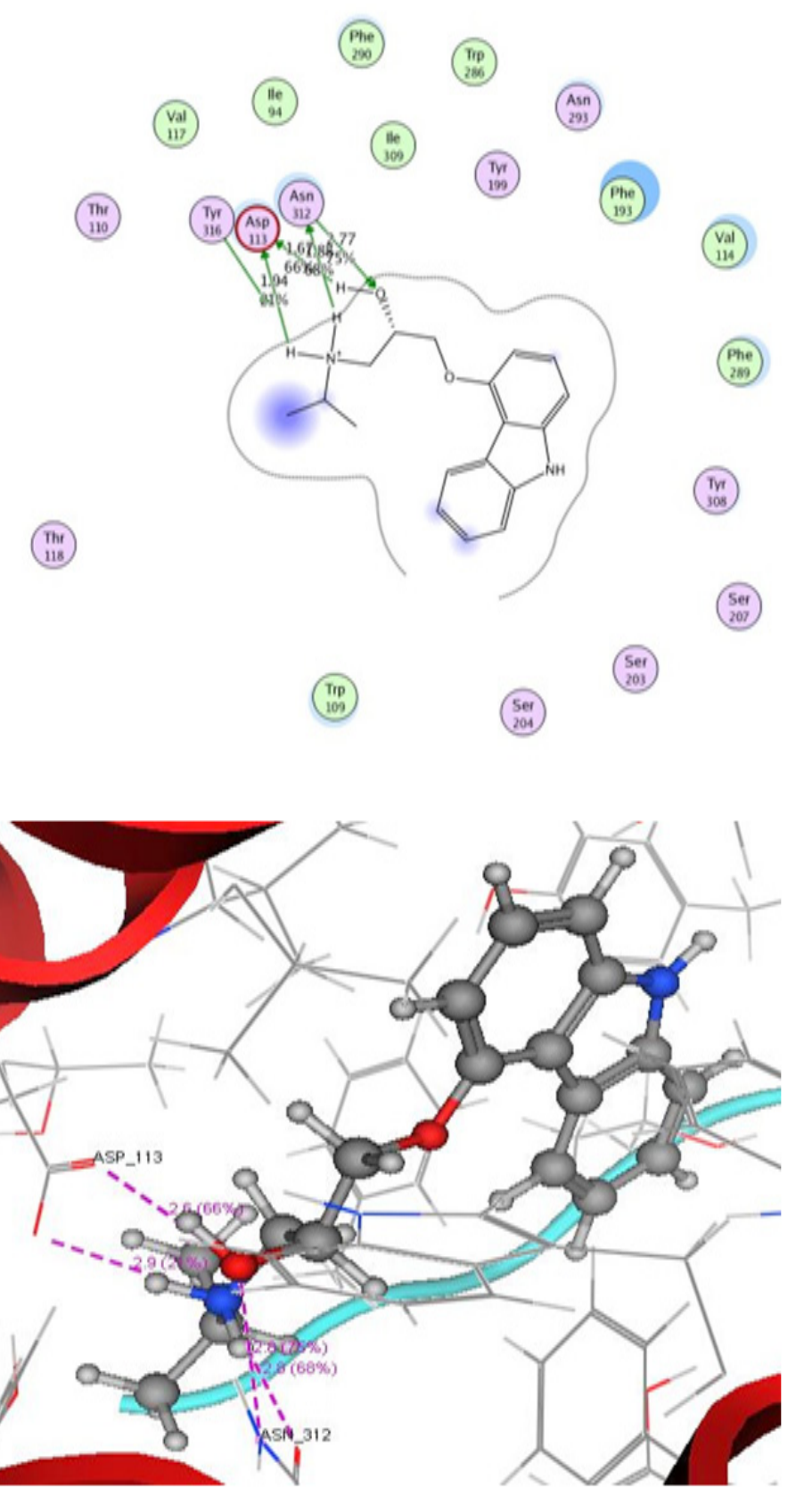

Fig. 8 2D and 3D interaction of Ligand (CAU), procaterol and radioiodinated procaterol with $\beta_{2}-$ adrenergic receptor respectively. 


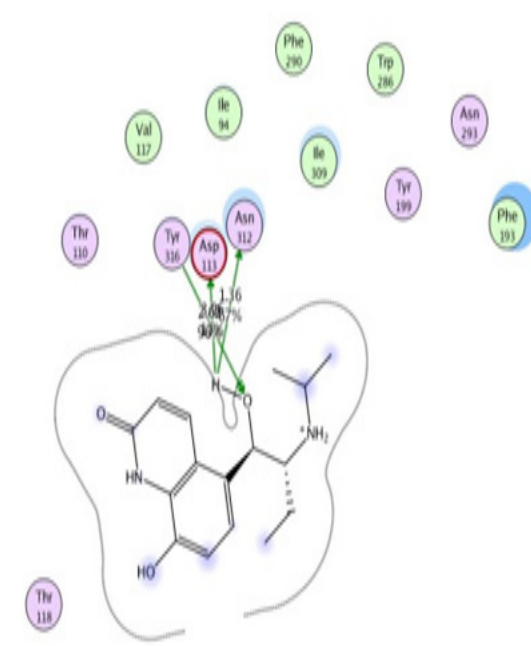

(vidi

(ance

(ina

(Set)

(iii) (3ii)

(5et)

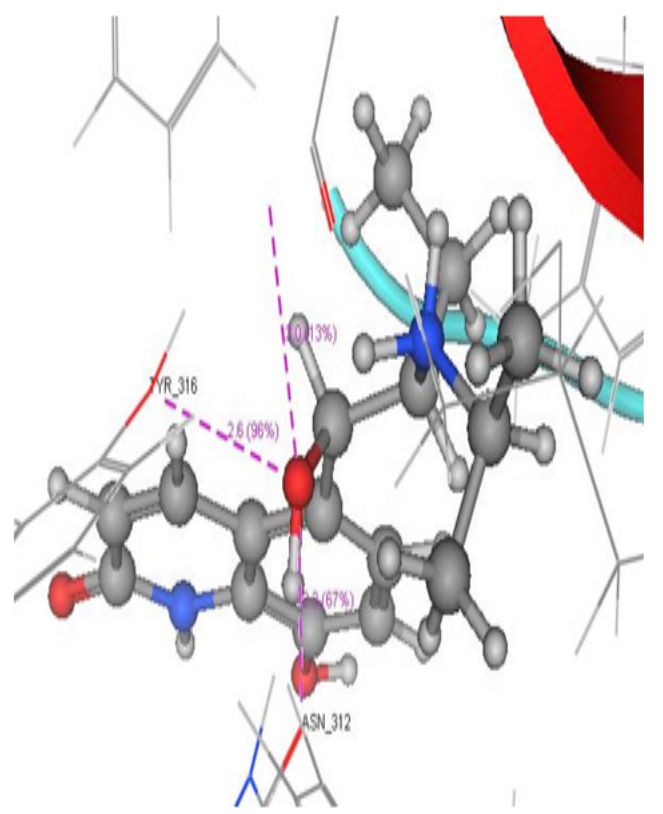

Fig. 9. 2D and 3D interaction of procaterol with $\beta_{2}$-adrenergic receptor respectively. 


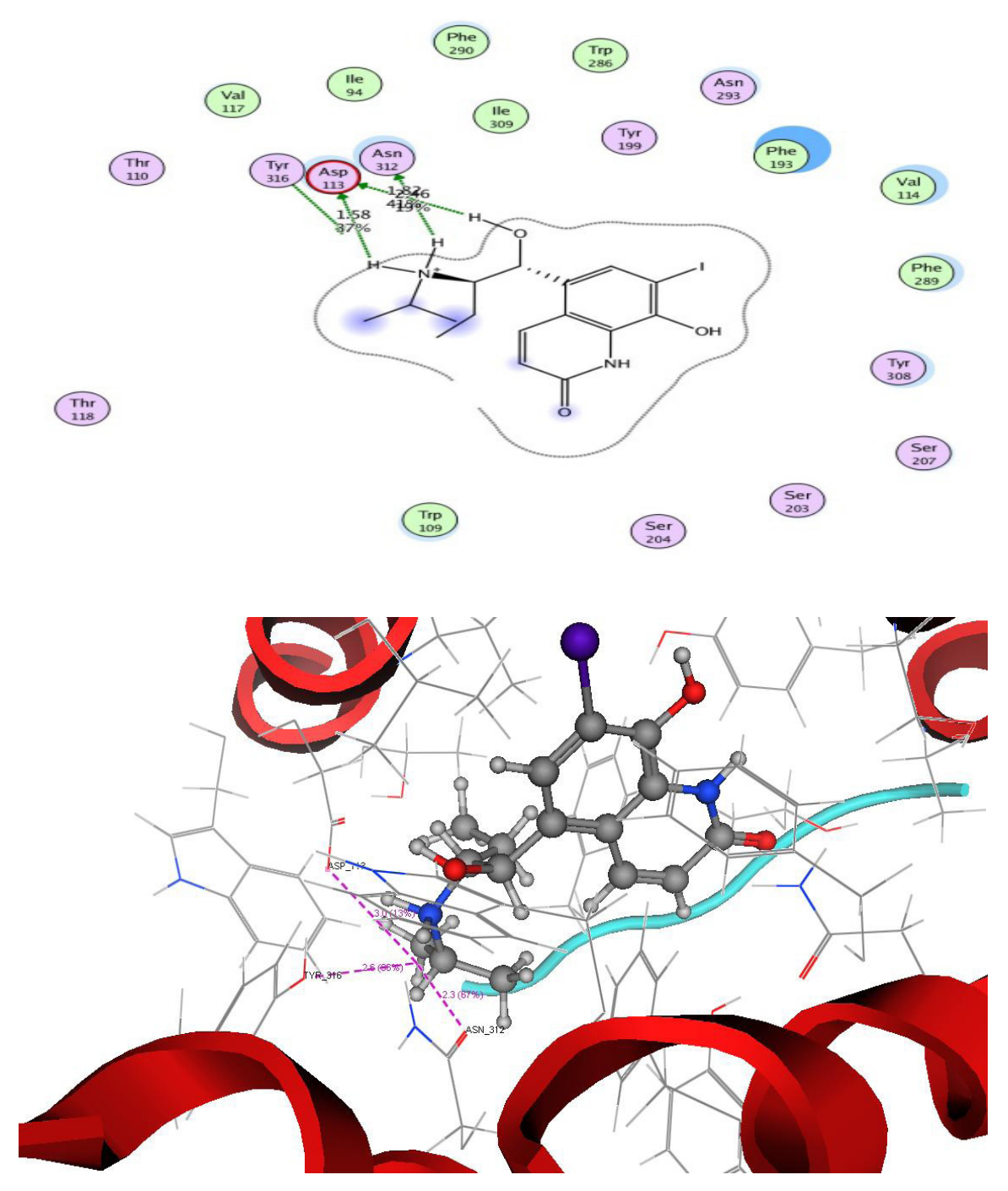

Fig. 10. 2D and 3D interaction of radioiodinated procaterol with $\beta_{2}$-adrenergic receptor respectively.

\section{References}

Akkas, B.E., Gokcora, N., Atasever, T., Yetkin, I. (2011) The use of technetium- $99 \mathrm{~m}$ hexamethylpropylene amine oxime lung scintigraphy in the detection of subclinical lung injury in patients with noninsulindependent diabetes mellitus. J. Nucl Med Commun.,32,1179.

Anu, S. and Puttaswamy P. (2013) Oxidation of tricyclic antidepressant drugs with chloramine- $T$ in acidic solutions: kinetic, mechanistic and thermodynamic studies. Springerplus.,2, 30.

Bajc, M., Neilly, J.B., Miniati, M., Schuemichen, C., Meignan, M., Jonson, B. (2009) EANM guidelines for ventilation/perfusion Scintigraphy Part 1 . Pulmonary imaging with ventilation/perfusion single photon emission tomography Eur $J$ Nucl Med Mol Imaging.,36,1370

Cherezov, V., Rosenbaum, D.M., Hanson, M.A., Rasmussen, S.G., Thian, F.S., Kobilka, T.S., Choi, H.J., Kuhn, P., Weis, W.I., Kobilka, B.K., Stevens, R.C. (2007) High-resolution crystal structure of an engineered human beta2-adrenergic $\mathrm{G}$ proteincoupled receptor. Science., 318, 1258

Dakshayani, S., Adalagere, S. M.,Puttaswamy. (2016) $\mathrm{PdCl}_{2}$ Catalyzed and Uncatalyzed N-Oxidation ofnaratriptanwith alkaline chloramine-T: delineation ofreactionmechanisms and kinetic Modelings.CatalLett.,146,180

De, K., Chandra, S., Sarkar, B., Ganguly, S., Misra, M. (2010) Synthesis and biological 
evaluation of ${ }^{99 \mathrm{~m}} \mathrm{Tc}-\mathrm{DHPM}$ complex: a potential new radiopharmaceutical for lung imaging studies , J.Radioanal Nucl Chem., 283,621.

Elgemeie, G.H., Farag, A.B. (2017) Design, synthesis, and in vitro anti-hepatocellular carcinoma of novel thymine thioglycoside analogs as new antimetabolic agents, Nucleoside \& Nucleotide and Nucleic acid., 36, 243 .

Gu, T. Shi, H., Xiu, Y., Gu, Y. (2011) Primary Pulmonary Osteosarcoma: PET/CT and SPECT/CT Findings, J. Clin. Nucl. Med., 36 (11),e209.

Hofman, M.S., Beauregard, J.M., Barber, T.W., Neels, O. C., Hicks, R.J. (2011) 68Ga PET/CT ventilationperfusion imaging for pulmonary embolism: a pilot study with comparison to conventional scintigraphy. J. Nucl. Med.,52,1513.

Klaus, Z., Claudia, B.S., Jörg, P., Joachim,K. (2009) Ventilation/perfusion lung scintigraphy: what is still needed? A review considering technetium99m-labeled macro-aggregates of albumin, Annals of Nuclear Medicine., 23, 1.

Miroslavov, A.E., Gorshkov, N.I., Lompov, A.L., Yalfimov, A.N., Suglobov, D.N., Ellis, B.L., Braddock, R., Smith, A., Prescott, M.C., Lawson, R.S., Sharma, H.L.(2009) Evaluation of 99mTc (CO) 5 I as a potential lung perfusion agent. J. Nucl. Med Bio., 36 (1),73

Molecular Operating Environment (MOE). (2013) 2008.10.,Chemical Computing Group Inc., 1010 Sherbooke St. West, Suite \#910, Montreal, QC, Canada., H3A, 2R7..

Naïm, M., Bhat, S., Rankin, K.N., Dennis, S., Chowdhury, S.F., Siddiqi ,I., Drabik, P., Sulea, T., Bayly, C.I., Jakalian, A., Purisima, E.O.(2007) Solvated interaction energy (SIE) for scoring protein-ligand binding affinities. 1. Exploring the parameter space.J. Chem. Inf. Model.,47,122

Paul, L.(2009) Protonate3D: Assignment of ionization states and hydrogen coordinates to macromolecular structures. Proteins., 75, 187

Parker, J.A., Coleman, R.E., Grady, E., Royal, H.D., Siegel, B.A., Stabin, M.G., Sostman, H.D., Hilson, A.J., (2012) SNM practice guideline for lung scintigraphy 4.0. J. Nucl. Med.Technol.,40 (1), 57.

Richard, R.G., Harry, H., Jagadeesh, R.V. (2013) Puttaswamy. 2001."e-EROS encyclopedia of reagents for organic synthesis", John Wiley \& Sons, Ltd, Published Online:.
Sanad, M.H. and Emad, H.B. (2015) Comparative biological evaluation between $99 \mathrm{mTc}$-tricarbonyl and $99 \mathrm{mTc}-\mathrm{Sn}$ (II) levosalbutamol as a $\square 2$ adrenoceptor agonist Radiochim. Acta., 103 (12), 879

Satpati, D., Bapat, K., Mukherjee, A., Banerjee, S., Kothari, K., Venkatesh, M. (2006) Preparation and bioevaluation of $99 \mathrm{mTc}$-carbonylcomplex of 5-hydroxy tryptamine derivative. Appl. Rad. Isot. 64 (8), 888-892

Simon, S. L., Bouville, A. L., Charles, E. (2006) Fallout from Nuclear Weapons Tests and Cancer Risks". American Scientist, 94, 48-57.

Silberstein, S. D. (2000) Practice parameter: Evidencebased guidelines for migraine headache (an evidence-based review): Report of the Quality Standards Subcommittee of the American Academy of Neurology. Neurology, 55(6), 754-762.

Thomas, D.G., Anderson, R.E., du Boulay, G.H. (1984) CT-guided stereotactic neurosurgery: experience in 24 cases with a new stereotactic system. J. Neurol. Neurosurg Psychiatry, 47(1), 9-16.

Sakr, T.M.(2014) Synthesis and preliminary affinity testing of 123I/125I-N-(3-Iodophenyl)-2-methylpyrimidine-4,6-diamine as a novel potential lung scintigraphic agent. Radiochemistry., 56,170.

Seute, T., Leffers, P., Velde, G.P. (2008) Twijnstra A. Detection of brain metastases from small cell lung cancer: consequences of changing imaging techniques (CT versus MRI). Cancer.,112 (8),1827.

Yang, G., Wang, X., Wang, Z., Jiang, Y., Fu, J., (2011) Tc-99m MDP uptake in a giant pulmonary chondroma. J. Clin. Nucl. Med., 36 (11),1029.

(Received 15/8/2017; accepted 20/9/2017) 


\title{
دراسة المحاكاة بالحاسب الألى وتقييم ما قبل السريرية للبروكاتيرول المرقم باليود المشع كعامل دقيق لتصوير الرئة
}

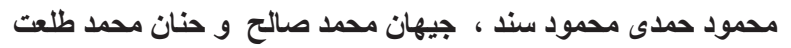

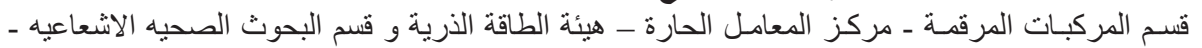
المركز القومي لبحوث و تكنولوجيا الاشعاع- هيئة الطاقة الذرية.

\begin{abstract}
تم ترقيم البروكاتيرولباليود المشع_ه با بأستخدام الكلور امين-ت كعامل مؤكسد والذى من الممكن أستخدامة

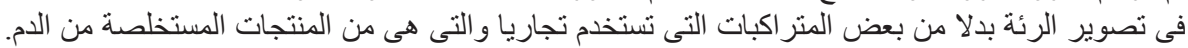

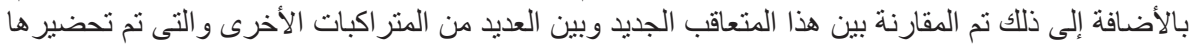

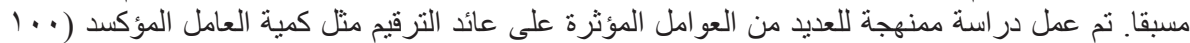

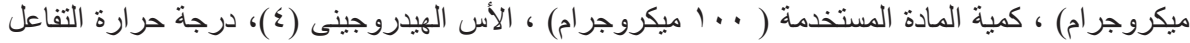

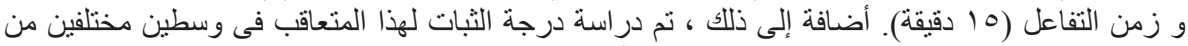

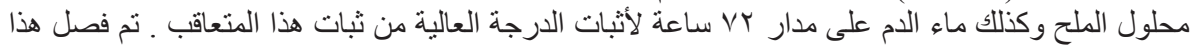

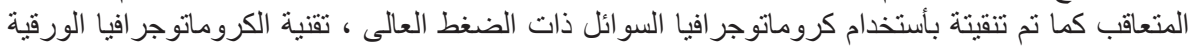

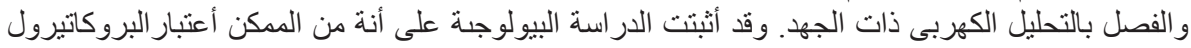

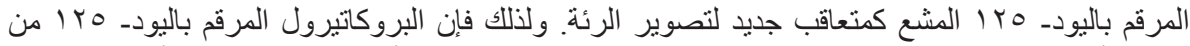

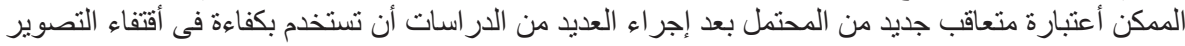

الأشعاعى للرئة.
\end{abstract}

